\title{
Cyclicality of real wages among young men
}

\author{
Donggyun Shin \\ Department of Economics, University of Michigan, Ann Arbor, MI 48109, USA
}

Received 16 September 1993; final revision received 28 February 1994; accepted 14 March 1994

\begin{abstract}
This paper analyzes the cyclical behavior of real wages received by the young men in the National Longitudinal Surveys of labor market experience. It extends the studies by Bils (Journal of Political Economy, 1985, 93, 666-689) and Tremblay (Quarterly Review of Economics and Business, 1990, 30, 90-101) by using the full duration of the survey and by examining differences in wage cyclicality across industries and between workers that change employers and those that stay with the same employer.
\end{abstract}

JEL classification: $\mathrm{E} 24$

\section{Introduction}

On the basis of aggregated time-series evidence, macroeconomists typically have described weak cyclicality of real wages as a salient feature of the business cycle. As first pointed out by Stockman (1983), however, aggregate wage series are countercyclically biased by their tendency to weight low-skill workers more heavily in expansion than in recessions. Numerous recent analyses of longitudinal micro data, which have avoided this composition bias by following the same workers over time, have found real wages to be considerably procyclical. For example, using 1966-80 data on young men in the National Longitudinal Surveys (NLS) of labor market experience, Bils (1985) estimated that a $1 \%$ rise in the unemployment rate is associated with a fall in real wages of $1.6 \%$ for whites and $1.8 \%$ for blacks. Tremblay's (1990) analysis of 1966-78 data on the NLS young men produced estimates of $1.5 \%$ for whites and $1.6 \%$ for non-whites. Studies based on the Panel Study of Income Dynamics (PSID) have generated similar results. ${ }^{1}$

This present paper extends the NLS-based studies by Bils and Tremblay by incorporating data through 1981 and by investigating two types of heterogeneity in real wage cyclicality. First, it examines the difference in wage cyclicality between workers that change employers

${ }^{1}$ See Solon et al. (1992) for one study and a review of others. 
and those that stay with the same employer. This investigation is motivated by Bils' finding that, although changers experience hugely procyclical real wages, "The wages of those who stay at the same job are only slightly procyclical", perhaps because of wage smoothing in implicit contracts. On the other hand, Solon et al.'s (1992) PSID-based study found lots of procyclicality, even among stayers. This seems to suggest that even career employers have to adjust wages in response to cyclical fluctuations if they wish to recruit and retain the desired workers.

Second, I examine interindustry differences in wage cyclicality. It is commonly believed that interindustry wage gaps move countercyclically. For example, McDonald and Solow (1985, p. 1116) write:

... the relative wage differential between the primary and secondary sectors widens as the overall labor market weakens and narrows as it tightens... For the United States, we think of high-wage manufacturing, especially durable goods, as the prototype of the primary sector, and of trade and small-scale services as the prototype of the secondary sector.

For this stylized fact to be true, high-wage industries should experience less procyclical real wage movement than low-wage industries. From a theoretical point of view, the 'fact' is surprising because labor demand is more cyclically sensitive in manufacturing than in trade and services, so, if industry labor supply curves are positively sloped, one might expect greater wage cyclicality in manufacturing. Theorists like McDonald and Solow therefore have developed elaborate models to account for the supposed countercyclicality of interindustry wage gaps. ${ }^{2}$ Recent empirical work by Wood (1992), however, has questioned the validity of the stylized fact that motivated these models. Because Wood's data from aggregate time series and repeated cross-sections may be subject to composition biases, it is worthwhile to reexamine this issue with longitudinal data from the NLS.

\section{Data and econometric model}

The NLS interviewed 5,225 males aged 14-24 as of 1966 and tracked them for 12 of the 16 years from 1966 to 1981. I pooled the data over individuals and years and imposed sample restrictions so that the pooled sample includes only those who finished schooling and are not self-employed. Because I analyze year-to-year changes in wages, individuals were included in the pooled sample for every two consecutive interviews in which they reported wages. The resulting sample contains 15,952 observations of individuals' year-to-year changes.

The model for real wages is

$$
\log W_{i t}=\beta_{1}+\beta_{2} t+\beta_{3} t^{2}+\beta_{4} X_{i t}+\beta_{5} X_{i t}^{2}+\beta_{6}^{\prime} Z_{i}+\beta_{7} U_{t}+v_{i t},
$$

where $W_{i t}$ is the ratio of the current nominal wage reported by individual $i$ in year $t$ to the implicit GNP deflator (Table B-3, Economic Report of the President, President of the United States, 1991). Work experience, $X_{i r}$, is measured simply as the number of years since individual $i$ completed schooling. $Z_{i}$ is a vector of individual-specific but time-independent characteristics such as years of schooling, race, ability, and motivation. The national civilian unemployment rate, $U_{t}$ (Table B-40, Economic Report of the President, 1991), is used as a

${ }^{2}$ See Wood (1992) for references to other such models. 
cycle indicator, and $v_{i t}$ is a random error term. $\beta_{7}$ is greater than, equal to, or less than 0 as real wages move countercyclically, acyclically, or procyclically.

A convenient way to control for unmeasured as well as measured elements of $Z_{i}$ is to 'difference out' their effects by subtracting from Eq. (1) the equation for the preceding period. This produces

$$
\begin{aligned}
\log \left(W_{i t} / W_{i, t-s}\right)= & 2\left(\beta_{3}+\beta_{5}\right)+\left(\beta_{2}-3 \beta_{3}+\beta_{4}-3 \beta_{5}\right) s+2 \beta_{3}(s \cdot t)+2 \beta_{5}\left(s \cdot X_{i t}\right) \\
& +\beta_{7}\left(U_{t}-U_{t-s}\right)+\left(v_{i t}-v_{i, t-s}\right),
\end{aligned}
$$

where $s$ equals 1 or 2 according to whether the most recent interview before the year $t$ interview was one or two years earlier. In particular, $s=2$ for the 1971-73, 1973-75, 1976-78, and 1978-80 observations of Eq. (2).

That some observations are differenced over two years and others over one year has two econometric implications. First, as noted by Bils, the variance of the error term in Eq. (2) is greater when $s=2$ than when $s=1$ if $\operatorname{Corr}\left(v_{i t}, v_{i, t-2}\right)<\operatorname{Corr}\left(v_{i t}, v_{i, t-1}\right)$. This calls for a heteroskedasticity correction. A second implication, overlooked by Bils, is that $s$ and its interactions with $t$ and $X_{i t}$ should appear as regressors in Eq. (2).

Another econometric issue is that the error term in Eq. (2) is likely to be cross-sectionally correlated bccause different individuals' error terms share common time effects. Therefore, to obtain appropriate standard error estimates, I break the estimation of Eq. (2) into two steps. First, I apply weighted least squares to the regression of $\log \left(W_{i t} / W_{i, t-s}\right)$ on $\left(s \cdot X_{i t}\right)$ and a vector of year dummies. [To determine the appropriate weighting to correct for heterokedasticity, I previously applied ordinary least squares (OLS) to this regression and used the OLS residuals to estimate that the error variance is 1.37 times greater when $s=2$ than when $s=1$. $]^{3}$ Second, I apply OLS to the regression of the estimated year effects of $s, s \cdot t$, and $U_{t}-U_{t-s}$. The estimated coefficient of $U_{t}-U_{t-s}$ is my estimate of the wage cyclicality parameter $\beta_{7}$.

\section{Empirical results}

Table 1 displays my basic estimates of $\beta_{7}$. Like Bils and Tremblay, I present the estimates separately for whites and blacks. As in most recent studies using micro panel data, real wages move procyclically. A one percentage point rise in the unemployment rate decreases real wages by $1.65 \%$ for whites and $1.43 \%$ for non-whites. These estimates are quite similar to the estimates Bils and Tremblay obtained from shorter panels.

\footnotetext{
${ }^{3}$ In addition to the heteroskedasticity problem, the error term in the first-step wage growth equation is subject to a negative first-order autocorrelation. Neglecting this serial correlation reduces the efficiency of the estimated year effects, but does not distort the estimated standard errors in the second stcp.

${ }^{4}$ These estimates also imply an unemployment elasticity of real wages similar to the -0.1 figure that Blanchflower and Oswald (1992) estimated with respect to regional unemployment rates. The similarity is surprising at first if one expects the greater elasticity of regional labor supply (due to interregional mobility) to induce a smaller wage response. On the other hand, Blanchflower and Oswald's dependent variable was log annual earnings, so their estimates were inflated by the inverse relationship between the unemployment rate and annual hours of work.
} 
Table 1

Overall cyclicality

\begin{tabular}{llll}
\hline & Sample period & Whites & Blacks \\
\hline Bils & $1966-1980$ & -0.0159 & -0.184 \\
Tremblay & & $(0.0033)$ & $(0.0053)$ \\
& $1966-1978$ & -0.015 & -0.016 \\
Current study & $1966-1981$ & $(-)$ & $(-)$ \\
& & -0.0165 & -0.0143 \\
& & $(0.0025)$ & $(0.0076)$ \\
\hline
\end{tabular}

Since $86 \%$ of the 15,952 observations are at ages $20-34$, I reestimated $\beta_{7}$ with $U_{t}$ measured by the unemployment rate for men in that age range. This specification generated estimates of $1.31 \%$ for whites and $1.08 \%$ for non-whites. These smaller estimates are due to the greater cyclical variation of unemployment rates of young men. ${ }^{5}$ In the remainder of this paper I will revert to using the overall unemployment rate to facilitate comparisons with the previous literature.

Next I split the sample of 15,952 observations into those that involve changes of employer and those that do not. My separate estimates of $\beta_{7}$ for stayers and changers are shown in Table 2. Like Bils, I find tremendous wage procyclicality for changers. My estimate of $\beta_{7}$ for black stayers is even smaller than Bils', but is very imprecise. My estimate for white stayers is considerably more procyclical than Bils' and very close to the -0.0124 estimate that Solon et al. reported for stayers in the PSID. Although wages are undoubtedly more procyclical for changers than stayers, there is some evidence that stayers experience substantial wage procyclicality, too.

Finally, I investigate interindustry differences in wage cyclicality by expanding Eq. (1) to include a vector of industry dummy variables and their interactions with $U_{t}$. For simplicity, I pool whites and blacks together and apply OLS to the differenced version of the expanded model. (Note that the estimated standard errors are probably biased downward by their neglect of the cross-sectional correlation of error terms.) The resulting industry-specific

Table 2

Employer changers/stayers

\begin{tabular}{llllll}
\hline & Stayers & & & \multicolumn{2}{l}{ Changers } \\
\cline { 2 - 3 } \cline { 5 - 6 } & Whites & Blacks & & Whites & Blacks \\
\hline Bils & -0.0064 & -0.0044 & & -0.0369 & -0.0439 \\
\multirow{2}{*}{ Current study } & $(0.00398)$ & $(0.00647)$ & & $(-)$ & $(-)$ \\
& -0.0118 & -0.0019 & & -0.0267 & -0.0380 \\
& $(\mathbf{0 . 0 0 2 7 4 )}$ & $(0.00646)$ & & $(0.00557)$ & $(0.01143)$ \\
\hline
\end{tabular}

\footnotetext{
${ }^{5}$ Also, at the referee's suggestion, I reestimated $\beta_{7}$ with 'balanced' samples (the 152 whites and 41 blacks who had valid wage observations in every year of the sample period). The resulting estimates, $1.01 \%$ for whites and $1.65 \%$ for blacks, are very imprecise because of the small sample sizes.
} 
Table 3

Industry-specific cyclicality

\begin{tabular}{lc}
\hline & Estimates \\
\hline Agriculture, forestry, fisheries & 0.160 \\
Mining & $(0.0084)$ \\
& -0.0280 \\
Construction & $(0.0102)$ \\
& -0.0244 \\
Manufacturing & $(0.0041)$ \\
& -0.0192 \\
Transportation, communication & $(0.0025)$ \\
public utilities & -0.0193 \\
Wholesale, retail trade & $(0.0048)$ \\
& -0.0046 \\
Financc, insurancc, rcal cstatc & $(0.0033)$ \\
& -0.0138 \\
Public administration & $(0.0071)$ \\
& -0.0161 \\
Services (business and repair, & $(0.0063)$ \\
pcrsonal, cntcrtainmcnt and & -0.0108 \\
recreation, professional) & $(0.0039)$ \\
\hline
\end{tabular}

estimates of $\beta_{7}$ are shown in Table 3. All industrics except agriculture exhibit procyclical wage patterns.

Despite the likely bias in the estimated covariance matrix, an $F$-test rejects the hypothesis of interindustry homogeneity in wage cyclicality at even the 0.01 significance level. But the pattern of the point estimates is not at all consistent with the conventional view of countercyclical interindustry wage gaps. Instead, the magnitudes of the industry-specific procyclicalities are negatively correlated with industry mean wages, and, in particular, the manufacturing sector shows a more procyclical wage movement than the trade or the services sector.

\section{Acknowledgements}

I am grateful to Gary Solon for his extremely helpful comments and suggestions and Sungjoon Min for computing help.

\section{References}

Bils, M.J., 1985, Real wages over the business cycle, Journal of Political Economy 93, 666-689.

Blanchflower, D.G. and A.J. Oswald, 1992, International wage curves, Working paper no. 4200, National Bureau of Economic Research, Cambridge, MA. 
McDonald, I.M. and R.M. Solow, 1985, Wages and employment in a segregated labor market, Quarterly Journal of Economics 100, 1115-1141.

President of the United States, 1991, Economic report of the President (United States Government Printing Office, Washington DC).

Solon, G., R. Barsky and J.A. Parker, 1992, Measuring the cyclicality of real wages: How important is composition bias? Working paper no. 4202, National Bureau of Economic Research, Cambridge, MA.

Stockman, A.C., 1983, Aggregation bias and the cyclical behavior of real wages, unpublished manuscript.

Tremblay, C.H., 1990, Wage patterns of women over the business cycle, Quarterly Review of Economics and Business 30, 90-101.

Wood, R.G., 1992, Interindustry wage differences over the business cycle, chapter 3 in unpublished Ph.D. dissertation, University of Michigan, Ann Arbor, MI. 